\title{
Gender and Roll Call Voting Behavior in Congress: A Cross-Chamber Analysis
}

\author{
Brian Frederick
}

\begin{abstract}
Numerous studies have examined the roll call voting behavior of women in Congress. Much of this scholarship has focused on whether female legislators tend to be more liberal than their male colleagues. However, most of this research has examined whether gender differences exist within a specific legislative chamber. This paper seeks to build on this past research by exploring whether the relationship between the descriptive and substantive representation of women is contingent upon the institutional context in which female legislators serve. Using Common Space Scores which estimate the roll call voting behavior of U.S. Senators and U.S. House members on a scale that allows for comparisons across each chamber this study analyzes the voting records of Female Senators, Male Senators, Female House Members and Male House Members in the 109th-111th Congresses. The results show that in the contemporary Congress, gender exerts minimal influence on how legislators cast their votes with the exception of female Republican Senators who are noticeably more liberal than Republicans in both the House and Senate.
\end{abstract}

As the ranks of women elected to national office continues to steadily grow researchers studying the tangible implications of this development have more opportunities than ever before to make sense of what it means for the substantive policy interests of women. Do women as proponents of descriptive representation suggest, act in ways that are fundamentally different from male politicians serving in the same positions? One area of policy activity that has spawned a fruitful line of research on this topic is the roll call voting behavior of women in Congress. Generally the conclusion of much of this scholarship is that women do exhibit patterns of voting distinctive from their male colleagues (for an extensive review of this literature see Reingold 2008). Whether looking at multiple indices of liberalism or conservatism or at specific issues substantively related to the concerns of women a wide array of scholars has established that women tend be to the left of their male colleagues (Burrell 1994; Clark 1998; Dodson 2006; Dolan 1997; Francovic 1977; Frederick 2011; Pearson 2009; Rocca et al. 2008; Swers 1998 and 2002; Tatalovich and Schier 1993; Welch 1985). In spite of this evidence an emerging line of studies have begun to question the conventional wisdom (Frederick 2009; Schwindt-Bayer and Corbetta 2004; Simon and Palmer 2010). The message emanating from this line of scholarship is that gender is not a significant variable when it comes to predicting how members of Congress are positioned on the ideological spectrum. 
So how does one reconcile these conflicting findings? The problem with most of the existing research is that it explores whether gender differences exist within a specific legislative chamber, most frequently the U.S. House of Representatives. The chief argument of this paper is that understanding the relationship between gender and substantive representation in the U.S. Congress requires investigating it across institutions. In the highly polarized House of Representatives, the structure of the rules in this body diminishes the influence of gender in the process of voting on policy outcomes. Conversely, the institutional rules of the Senate and its individualistic culture may produce conditions that allow for gender differences in roll call voting to be more readily identified than is possible in institutions where the rules are more rigidly structured like the U.S. House. Using Poole's (2005) Common Space Scores which estimate the roll call voting behavior of U.S. Senators and U.S. House members on a scale that allows for comparisons across each chamber this study analyzes the voting records of female Senators, male Senators, female House Members and male House Members in the 109th-111th Congresses. The results provide insight into whether the relationship between the descriptive and substantive representation of women is contingent upon the institutional context in which female legislators serve. In the contemporary Congress gender exerts minimal influence on how legislators cast their votes with the exception of female Republican Senators who are noticeably more liberal than all other Republicans in both the House and Senate.

\section{Gender and Representation in the House and Senate}

While the consensus arrived at by most of the relevant research is that female members of Congress have a tendency to be more liberal than their male colleagues, three recent studies of roll call voting in the House have raised doubts about the conventional wisdom. Scrutinizing 167 cases where one House member replaced another in the 104th and 105th Congresses, Schwindt-Bayer and Corbetta (2004) compared the roll call voting record of the member who replaced the previous serving member and generated an estimate of how much more liberal or conservative that voting record was. They uncovered no significant relationship between gender turnover and the change in the representative's roll call voting record. Simon and Palmer (2010) extended this analysis from 1937-2008 and also confirmed that male and female House members representing the same districts displayed very little variation in their voting records. Frederick's (2009) extensive time series analysis of voting patterns in the House from the 97th-109th Congresses reveals that while Republican women were once more liberal than their male colleagues in more recent congresses these differences have all 
but vanished. He maintains this result is an outgrowth of a polarized institution where Republican women feel substantial pressure to compile more conservative records in line with the national party platform.

Do the findings of this line of scholarship signify that gender has faded as a viable means to discern variation in the policy records of members of Congress? Some scholars have argued that the House of Representatives is not well situated to serve as a venue to assess the state of this relationship (Frederick 2010, 2011). Over the past generation the House has become a highly partisan institution where the ideological differences between the parties have dramatically intensified (Hetherington 2009; Jacobson 2000, 2009; Poole and Rosenthal 2007; Theriault 2008). As a result the majority party increasingly set up the rules to restrict the influence of the minority and individual members of the chamber (Cox and McCubbins 2005; Sinclair 2006). Therefore, it may not provide the optimal setting for examining the extent to which gender influences roll call voting behavior. In response several observers have insisted the Senate presents a more ideal institutional setting in which the legislative activities of male and female lawmakers can be distinguished (Frederick 2010, 2011; Osborn and Mendez 2010; Swers $2007,2008)$. When compared to the U.S. House, the structure of the rules in the Senate grants its members much greater latitude to exert their personal influence in the process (Pearson 2008; Sinclair 2009). In addition, the rules in the Senate allow members of the minority party to have a much greater voice in the legislative process (Binder and Smith 1997; Davidson et al. 2009; Gailmard and Jenkins 2008; Schickler 2005; Sinclair 2007; Wawro and Schickler 2006). The majority party in the Senate does not possess the same tools for controlling the agenda that are available to the majority party leadership in the House. The result is that a broader collection of issues that may not be a part of the majority party's agenda can be considered on the Senate floor, transmitting a much more complete record of a senator's legislative behavior (Lee 2008). This type of legislative environment may create conditions that increase the likelihood of patterns of support by gender in the Senate than is the case in the more firmly partisan House of Representatives. Indeed, Frederick's (2010) study of voting in the Senate over the past decade shows that Republican women in the Senate are demonstrably more liberal than male Senate Republicans.

Nevertheless, the empirical void in this line of research is that virtually all of it looks for gender effects in either the House or Senate separately. Without a joint comparison of the two chambers in a single study it is difficult to verify what impact if any, institutional context has on the connection between gender and policy representation among congressional lawmakers. Pearson's (2009) work in this area comes the closest to adopting such an approach. Her study compares the party unity scores of male and female 
members in both the House and Senate from the 103rd-110th Congresses. While the study sheds some light on the institutional variation in patterns of gender and voting behavior it falls short of relying on a directly comparable measure of members' records in both chambers. The composition of party unity votes can deviate quite dramatically in each chamber depending on what years are being examined.

In order to parse out the extent to which gender effects differs in the House and Senate it is essential to employ a measure that allows for the voting records of House and Senate members to be evaluated in the same policy space. Fortunately advances in spatial modeling have now made it possible to estimate the ideological position of representatives across legislative chambers (Shor et al. 2010). Common space scores are generated by scaling voting behavior of House and Senate members as if they served in the same legislature utilizing legislators who have served in both chambers as a bridge (Poole 2005). ${ }^{1}$ These scores provide the best available means for comparing the roll call voting records of House and Senate members across time and space. ${ }^{2}$ They range from -1 to +1 with higher values indicating a more conservative voting record. Up to this point, no published study investigating the role of gender in explaining voting behavior in Congress has employed these scores. Although largely absent in congressional research, Boyd et al. (2010) have successfully utilized judicial common space scores in their analysis of gender and voting on U.S. Courts of Appeals.

The next issue to resolve is over what period of time should these data be analyzed? Extended longitudinal analyses of gender and legislative activity in the U.S. House have shown that the nature of this relationship is very sensitive to the time frame examined (Frederick 2009). Ideally one could go back decades to explore voting behavior in the House and Senate. However, the numbers of women in the Senate have only recently made it possible to determine whether they are behaving in a substantively different fashion than their male colleagues. This statement is especially applicable to female Republicans who only reached a record high five senators following the appointment of Lisa Murkowski after the 2002 election. Although this number is far from optimal, preliminary studies of gender and legislative behavior in the Senate that these types of numbers have been sufficient to produce significant findings on this topic (Frederick 2010, 2011; Fridkin and Woodall 2005; Swers 2007, 2008; Osborn and Mendez 2010). Hence, it is necessary to limit this study's focus to the last few Congresses, which covers the 109th-111th Congresses (2003-2010). These three Congresses include a Republican controlled House and Senate during a Republican Presidency (109th, 2005-2006), a House and Senate controlled by Democrats during a Republican Presidency (110th Congress, 2007-2008) and unified Democratic control of the Congress and the Presidency (111th Congress, 2009- 
2010). This sample represents a wide variety of institutional and partisan contexts in which the dimensions of the relationship between descriptive and substantive representation in the House and Senate can be explored in order to assess the robustness of the findings.

\section{Descriptive Analysis}

This analysis of gender and voting in the House and Senate begins by examining the mean common space scores for the 109th-111th Congresses. Figures 1-3 plot these data broken down by party, gender and chamber. The patterns are remarkably similar for all three Congresses. As expected, in each Congress female House Democrats compile the most liberal voting record while male House Republicans compile the most conservative voting record. The mean score for female House Democrats ranges from -.48 in the 109th Congress and drifts a bit to the right -.45 in the 111th Congress. For male House Republicans, the range is .43 in the 109th rising to .47 in the 111th Congress. While these numbers indicate that the two most polarized groups in the modern Congress are in the House, there are large ideological gaps between other groups as well.

Generally however, it is party and not chamber or gender that produces the most noticeable differences. Male House Democrats, male Senate Democrats and female Senate Democrats cluster rather close together in all three

\section{Figure 1. Mean Common Space Scores by Gender, Party, and Chamber, 109th Congress}

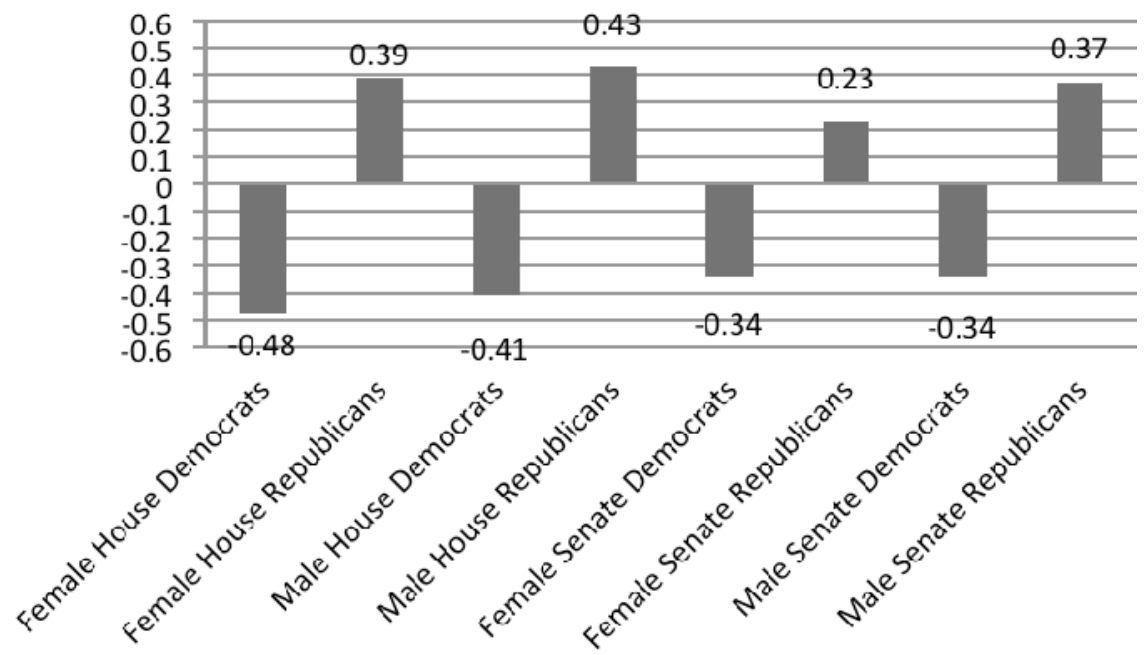


6 | Brian Frederick

Figure 2. Mean Common Space Scores by Gender, Party, and Chamber, 110th Congress
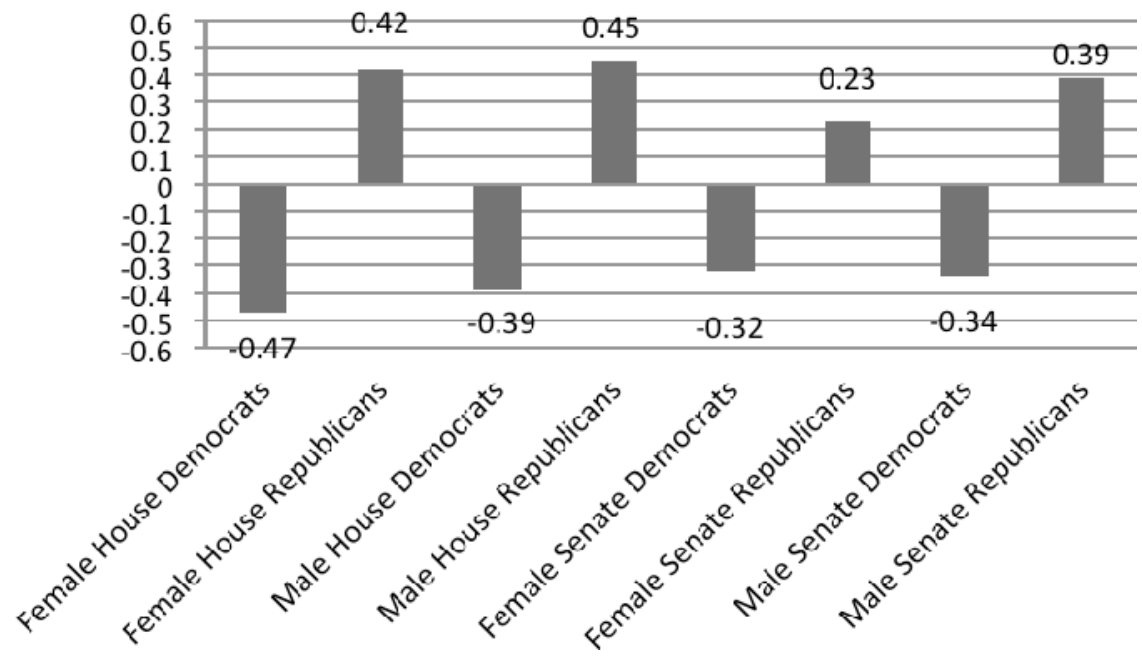

Figure 3. Mean Common Space Scores by Gender, Party, and Chamber, 111th Congress
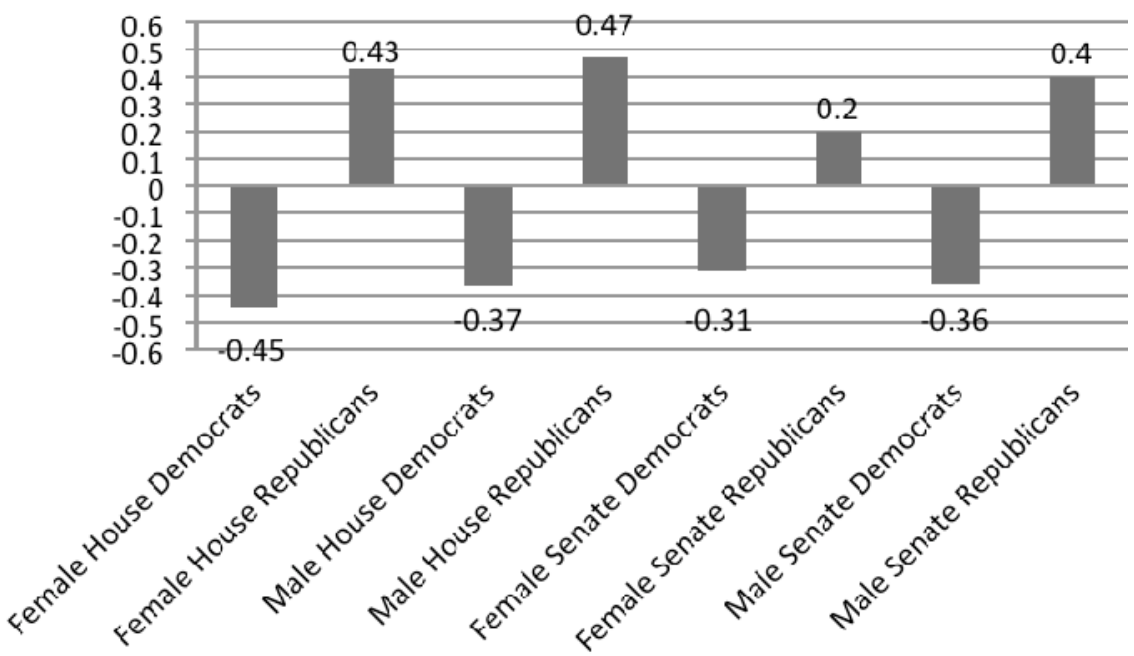
Congresses. Each group is positioned to the right of female Democrats with mean scores ranging from -.41 to -.31. Interestingly, female Senate Democrats are ever so slightly to the right of their male colleagues in all three Congresses. Most importantly, the magnitude of these differences is negligible revealing gender's influence on roll call voting behavior among Democrats in Congress is on display only when Female House Democrats are examined.

Part of the explanation for this difference can be accounted for by the fact that female House Democrats tend to represent more liberal constituencies (Frederick 2009; Gerrity et al. 2007; Palmer and Simon 2008). Figures 4-6 present the mean support received by Democratic presidential candidates for the most recent election in the state or district of the Senator or Representative. In the three Congresses, female House Democrats represent the most liberal constituencies with Democratic presidential candidates receiving around two-thirds of the vote in these districts. Using this measure of constituency liberalism male and female Senate Democrats represent nearly identical constituencies which illustrates why their voting records are so similar. Male House Democrats represent districts a few percentage points to the left of their Senate counterparts, which is also reflected in a mean voting record that is a bit to the left of male and female Senate Democrats. The general takeaway in looking at the roll call voting behavior of national Democratic politicians is that female House Democrats stand out for their

\section{Figure 4. Mean Percentage of Democratic Presidential Vote Share in the State or District by Gender, Party, and Chamber, 109th Congress}

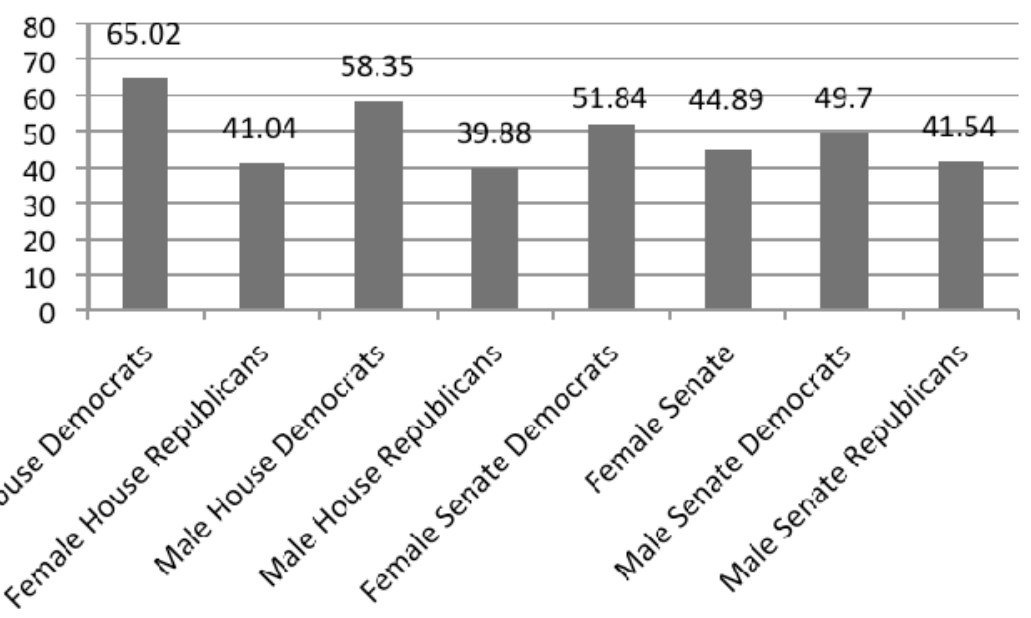


Figure 5. Mean Percentage of Democratic Presidential Vote Share in the State or District by Gender, Party, and Chamber, 110th Congress

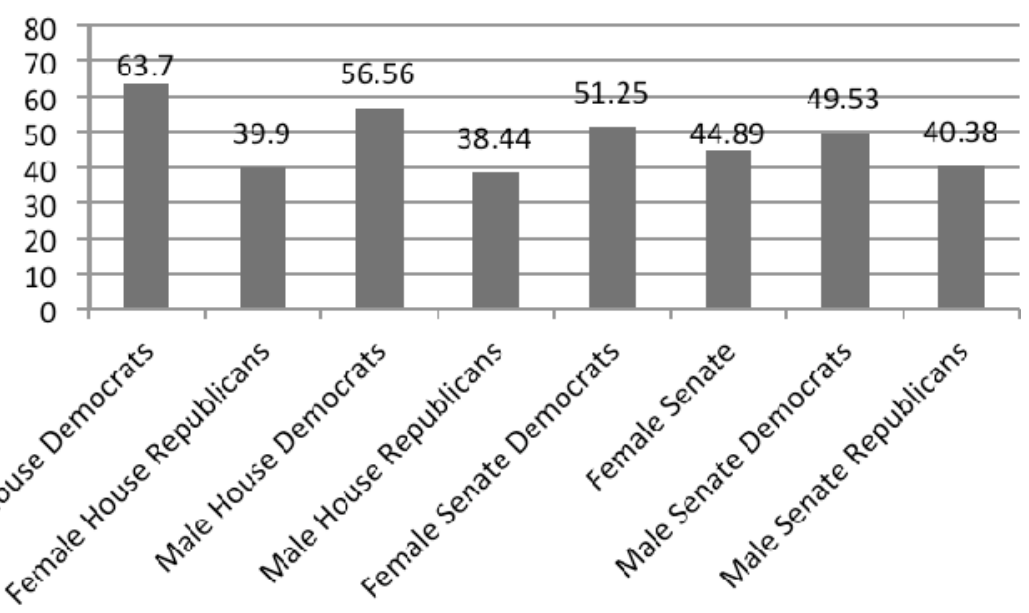

Figure 6. Mean Percentage of Democratic Presidential Vote Share in the State or District by Gender, Party, and Chamber, 111th Congress

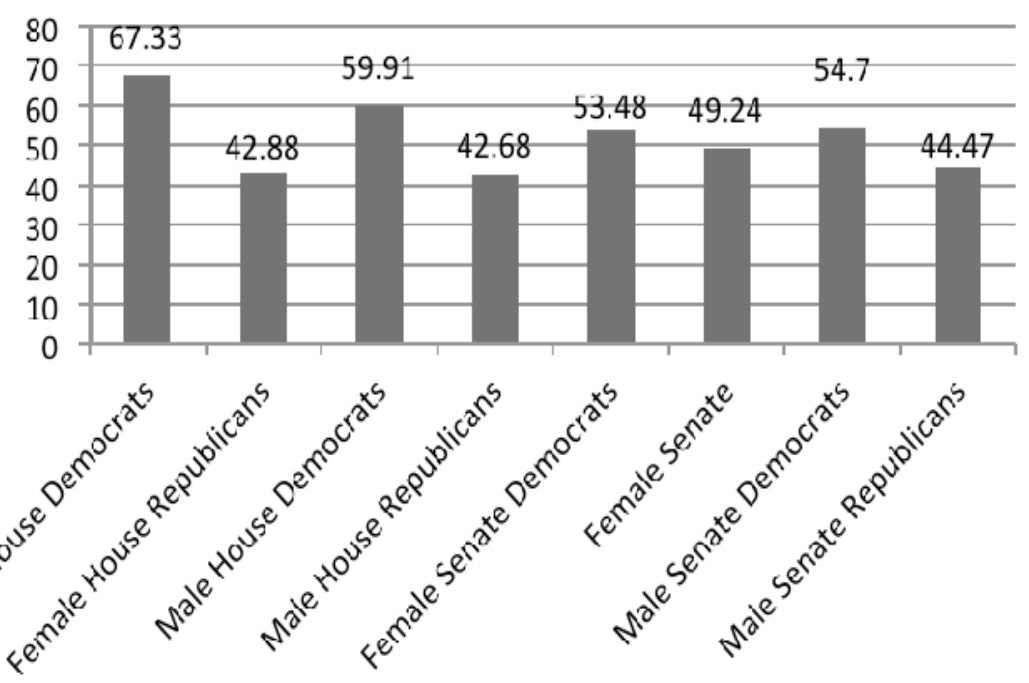


liberalism but in large part because their constituencies are so liberal. Otherwise, neither gender nor institution appears to carry much weight in explaining this phenomenon.

For congressional Republicans the story varies a bit. Female House Republicans and male Senate Republicans are a shade to the left of male House Republicans in the three Congresses but are generally in line with their ideological bent. The mean common space value for female House Republicans jumps from .39 in the 109th Congress to .43 in the 111th Congress. The results confirm the sharp rightward drift in female Republicans in the House demonstrated in previous research (Frederick 2009). Turning to the Senate, male Republicans have amassed a record largely in accord with their House colleagues during the past two Congresses. In the 109th Congress the mean common space score for male Senate Republicans was .37, rising to .40 in the 111th Congress. Analyzing the average level of support received by Democratic presidential candidates in these Republicans' states or districts shows why Republicans are so conservative over this period. This number is around 40 percent in each Congress for male and female House Republicans and male Senate Republicans. The conservative voting records of congressional Republicans are an outgrowth of the conservative nature of their constituencies.

The remaining group, female Senate Republicans, provide the most compelling evidence that gender is an influential variable in understanding patterns of voting behavior in Congress. For the three Congresses covered in this study women in Senate Republican Conference are noticeably to the left of the other Republicans in the House and Senate. The mean score for female Senate Republicans in the 109th and 110th Congress was .23. Not only are these averages significantly to the left of their fellow Republicans in both chambers $(\mathrm{p}<.05){ }^{3}$ the mean score for Republican women in the Senate actually moves to the left by the 111th Congress dropping to .20 . This movement is largely due to the defeat of Sen. Elizabeth Dole in the 2008 election. Nevertheless, this statistic does indicate that female Senate Republicans are the most ideologically distinctive group in the contemporary U.S. Congress and have become more so over the course of the study. The liberalism of their constituencies offers a partial explanation as to why they are more liberal than other national Republican officeholders. Democratic presidential candidates averaged about 45 percent of the vote for the 109th and 110th Congresses in states represented by female Senate Republicans. This number rose to 49.2 percent of the 111th Congress. Republican women in the Senate are representing states where the population leans to the left of other Republicans' constituencies and their voting records reflect that reality. The question remains whether the relative liberalism of Republican women in the Senate is a function of their more liberal constituencies or are 
the women in this institution voting differently after constituency effects are controlled for. The next section of this study presents the results of multivariate models that can help answer this question.

\section{Models Predicting Roll Call Voting Behavior}

The key independent variables in the models are a series of dummy variables representing male and female House Democrats, male and female Senate Democrats, male and female Senate Republicans and female House Republicans, with male House Republicans serving as the reference category. Similar coding strategies have been implemented in previous multivariate models predicting roll call ideology in Congress (Boles and Scheurer 2007: Frederick 2009, 2010). Since male House Republicans are likely to compile the most conservative voting records the coefficients for the remaining independent variables can be interpreted as how much less conservative each category of members is relative to the omitted category.

Constituency preferences are strongly associated with the ideological positioning of members of Congress (Aldrich et al. 2008; Ardion and Garrand 2003; Brady and Schwartz 1995; Erikson and Wright 2008; Fleisher and Bond 2004; Frederick 2009, 2010; Jacobson 2000, 2009; Stonecash 2006). The ideological makeup of the member's district or state carries a great deal of weight in predicting how members cast their votes. The most liberal members of Congress are most likely to represent the most liberal constituencies and the most conservative members are most likely to represent the most conservative jurisdictions. For the models tested in this study constituency preferences were estimated by the percentage of the vote won by the Democratic presidential candidate in the state or district during the last election. Since the dependent variable in each model is a continuous measure, OLS regression is utilized as the estimation technique in this analysis.

Table 1 presents the parameter estimates for the models predicting roll call ideology in the 109th Congress, 110th Congress and the 111th Congress. Recall that the dependent variable, the legislator's Poole's common space score, ranges from -1.0 to +1.0 , with positive values indicating a more conservative voting record. The results are nearly identical for each model. As expected constituency preferences are strongly associated with roll call voting behavior. A one percent increase in constituency liberalism corresponds with a .01 units shift leftward in the member's voting record $(\mathrm{p}<.001)$. Turning to the impact of gender, party and institution, in all three specifications each category of office holders are to the right of male House Republicans, although the coefficients for male Senate Republicans and female Republicans are not statistically significant. We would expect each group of 


\section{Table 1. Models Predicting Common Space Scores by Gender, Party, and Chamber}

\begin{tabular}{|c|c|c|c|}
\hline Independent Variable & $\begin{array}{c}\text { 109th } \\
\text { Congress }\end{array}$ & $\begin{array}{c}\text { 110th } \\
\text { Congress }\end{array}$ & $\begin{array}{c}111 \text { th } \\
\text { Congress }\end{array}$ \\
\hline Adj. $\mathrm{R}^{2}$ & .919 & .929 & .918 \\
\hline Female House Democrats & $\begin{array}{l}-.696 * * \\
(.025)\end{array}$ & $\begin{array}{l}-.682 * * \\
(.022)\end{array}$ & $\begin{array}{l}-.693 * * \\
(.023)\end{array}$ \\
\hline Female House Republicans & $\begin{array}{l}-.027 \\
(.027)\end{array}$ & $\begin{array}{l}-.014 \\
(.027)\end{array}$ & $\begin{array}{l}-.027 \\
(.033)\end{array}$ \\
\hline Male House Democrats & $\begin{array}{l}-.681 * * \\
(.017)\end{array}$ & $\begin{array}{l}-.664 * * \\
(.015)\end{array}$ & $\begin{array}{l}-.676^{* *} \\
(.016)\end{array}$ \\
\hline Female Senate Democrats & $\begin{array}{l}-.662 * * \\
(.043)\end{array}$ & $\begin{array}{l}-.643 * * \\
(.037)\end{array}$ & $\begin{array}{l}-.670 * * \\
(.038)\end{array}$ \\
\hline Female Senate Republicans & $\begin{array}{l}-.151 * \\
(.056)\end{array}$ & $\begin{array}{l}-.151 * \\
(.053)\end{array}$ & $\begin{array}{l}-.203 * * \\
(.063)\end{array}$ \\
\hline Male Senate Democrats & $\begin{array}{l}-.685^{* *} \\
(.23)\end{array}$ & $\begin{array}{l}-.678 * * \\
(.021)\end{array}$ & $\begin{array}{l}-.714 * * \\
(.021)\end{array}$ \\
\hline Male Senate Republicans & $\begin{array}{l}-.014 \\
(.020)\end{array}$ & $\begin{array}{l}-.011 \\
(.020)\end{array}$ & $\begin{array}{l}-.026 \\
(.022)\end{array}$ \\
\hline Presidential Vote & $\begin{array}{l}-.008 * * \\
(.001)\end{array}$ & $\begin{array}{l}-.009 * * \\
(.001)\end{array}$ & $\begin{array}{l}-.009 * * \\
(.001)\end{array}$ \\
\hline Constant & $\begin{array}{l}.757 * * \\
(.024)\end{array}$ & $\begin{array}{l}.797 * * \\
(.021)\end{array}$ & $\begin{array}{l}.845^{* *} \\
(.023)\end{array}$ \\
\hline Adj. $R^{2}$ & .919 & .929 & .918 \\
\hline $\mathrm{N}$ & 538 & 547 & 550 \\
\hline \multicolumn{4}{|c|}{$\begin{array}{l}* \mathrm{p}<.01 * * \mathrm{p}<.001 \\
\text { Note: Table entries are OLS coefficients with estimated standard errors in parentheses. }\end{array}$} \\
\hline
\end{tabular}

Democrats to be significantly to the left of male House Republicans. However, these results confirm the descriptive data showing that female Senate Republicans are .15 units to the left in the 109th and 110th Congresses and .20 units to the left in the 111th Congress, relative to male House Republicans $(\mathrm{p}<.001)$.

To help better illustrate the substantive effects of gender, party and institution, Figures 7-9 plot the predicted common space scores for the eight categories of officeholders with constituency ideology set at its mean in the 109th-111th Congresses. The 95 percent confidence intervals for the estimates are shown in brackets. These graphic displays highlight several consistent patterns. First, unsurprisingly, partisanship supersedes both gender 
and institution in determining ideological positioning in the contemporary Congress. As the bars for the 95 percent confidence intervals show, there is no overlap between Democrats and Republicans in either body. Democrats cluster toward the liberal end of the spectrum while conservatives are confined to the conservative end. Beyond partisanship, the graphs reveal the conditional impact of gender. For the Democrats the predicted scores for each category overlap closely during the three Congresses. For the109th Congress, the range is -.34 to -.31 , for the 110 th -.33 to -.29 , and for the 111 th -.35 to -.30 . In the analysis of the descriptive data female House Democrats stood out as the most liberal group of House Democrats but once their propensity to represent very liberal districts is controlled for their voting records are very much in sync with the other Democrats in Congress both male and female. This finding supports the conclusions of recent studies of gender and voting behavior in Congress that the policy records of male and female Democrats have become indistinguishable once constituency effects are properly controlled for (Frederick 2009, 2010; Simon and Palmer 2010). In the present study this phenomenon is in evidence for the institutional settings of both the House and Senate.

Figure 7. Predicted Common Space Scores by Gender, Party, and Chamber, 109th Congress

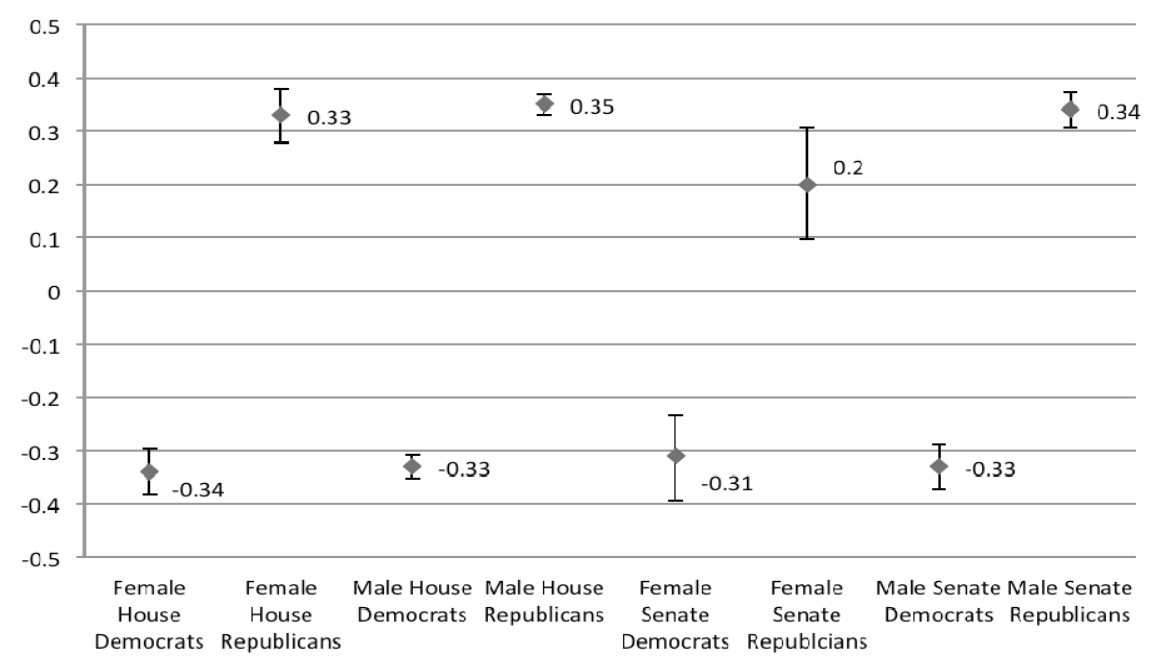

Note: The predicted scores are calculated by holding presidential vote at its mean. Bars represent the $95 \%$ confidence intervals for the estimated values. All predicted values calculated using CLARIFY software (Tomz et al. 2003). 
Figure 8. Predicted Common Space Scores by Gender, Party, and Chamber, 110th Congress

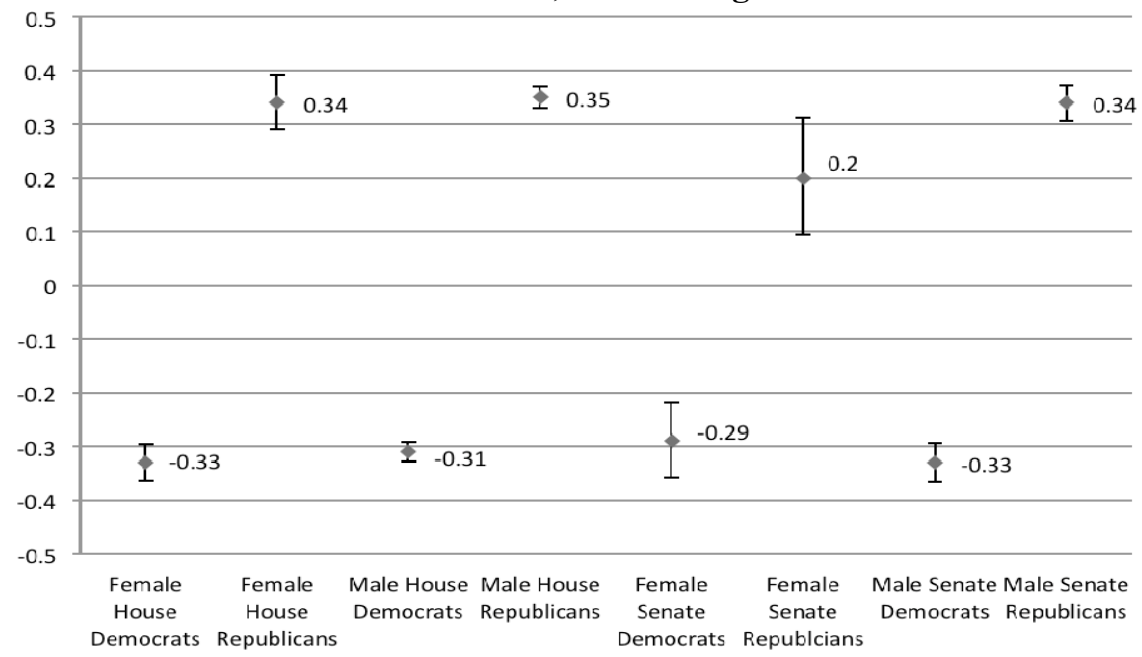

Note: The predicted scores are calculated by holding presidential vote at its mean. Bars represent the $95 \%$ confidence intervals for the estimated values. All predicted values calculated using CLARIFY software (Tomz et al. 2003).

Figure 9. Predicted Common Space Scores by Gender, Party, and Chamber, 111th Congress

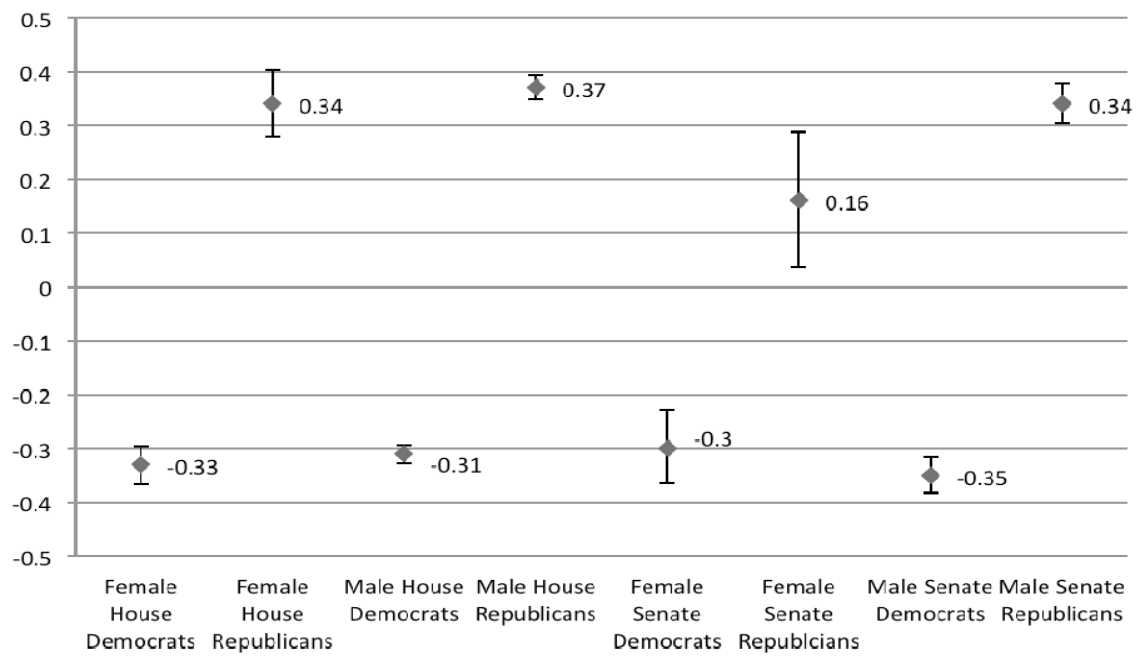

Note: The predicted scores are calculated by holding presidential vote at its mean. Bars represent the 95\% confidence intervals for the estimated values. All predicted values calculated using CLARIFY software (Tomz et al. 2003). 
Scrutinizing the graphs for the Republicans exposes the role gender and institutions play in influencing substantive representation. In the highly polarized House, gender matters very little, as the estimates for male and female Republicans overlap closely in the three Congresses. Male senators look very much like their House colleagues as their predicted scores are bunched closely together. For the three categories of members the estimates range from .33 to .35 for the 109th Congress, .33 to .35 for the 110th Congress, .34 to .37 for the 111 th Congress. The 95 percent confidence intervals for female House Republicans are much wider because of the small sample of these representatives but the data demonstrate that they are more similar than dissimilar in their voting behavior compared to male Republicans in Congress. The same statement cannot be made for female Senate Republicans. Figures 7-9 demonstrate that female Senate Republicans are considerably to the left of mainstream Republican positions on national policy issues. This tendency is not merely an artifact of representing more liberal constituencies than other Republicans as was the case with female House Democrats. The predicted common space score ranges from the .20 in the 109th Congress to .16 in the 111 th Congress. While there is some slight overlap in the confidence intervals in the 109th and 110th Congresses for the 111th Congress there is no overlap with the estimates for the other Republicans. The institutional conditions in the Senate allow gender to provide a moderating influence on a very conservative national Republican Party.

One high profile vote in the 111th Congress can help crystallize the implications of these empirical findings. Among the first issues tackled by Congress after the 2008 election was the Lilly Ledbetter Fair Pay Act. This legislation overturned a Supreme Court decision ${ }^{4}$ limiting the ability of victims of pay discrimination from filing claims against their employers (Sorok 2010). Enacting this law was one of the top priorities of women's groups and leading female members of Congress, including Speaker of the House Nancy Pelosi (Peters and Rosenthal 2010). When it came time to vote on final passage of the bill the two parties diverged substantially on whether to support it. The breakdown of the vote nearly perfectly captures the results uncovered in this study. In the House every single female House Democrat voted in favor of the bill and 100 percent of female House Republicans cast votes in opposition. ${ }^{5}$ Among the men all but 5 male House Democrats supported the bill while all but 3 male Republicans voted against it. In the Senate the partisan divide was similar with one exception. Every Senate Democrat voted for final passage and every single male Republican rejected it. $^{6}$ The one group departing from the partisan orthodoxy was the small contingent of women in Senate GOP Conference. All of them supported the bill including the more conservative women in the Republican Conference like Lisa Murkowski and Kay Bailey Hutchinson. Obviously not all votes break 
down as cleanly as this example would suggest. ${ }^{7}$ Republican women in Senate side with their male GOP colleagues more often than they do with Democrats. Even so, it underscores the unique brand of representation this group of women is providing.

\section{Conclusion}

The numerical representation of women in Congress continues on an upward trajectory, even if those gains have been more incremental than many advocates of greater diversity would like. Scholars of women in American politics have labored to figure out just what impact greater descriptive representation has had on substantive representation. Past studies have generated mixed results in attempts to isolate the effects of gender raising doubts about whether this variable is a relevant factor in deciphering how national legislators cast their votes on the issues that come before the Congress. Using common space scores for the 109th-111th Congresses, which up to this point have not been employed in gender based studies of legislative behavior, this study has highlighted how this relationship matters in the process of roll call voting and under what conditions it matters. It has demonstrated how the presence of women can result in tangibly different policy outcomes and when the influence of gender is more limited. These results allow us to put the inconsistent findings of recent studies in the proper context and clarify when gender is a significant predictor of differences in roll call voting behavior. There are three key observations that should be taken away from this analysis.

First, claims that gender offers little explanatory leverage in understanding the voting records of members of Congress can only be partially validated here. In the modern House of Representatives partisan polarization is so deep that over the past few Congresses gender differences are imperceptible once constituency effects are controlled for. This study confirms the most recent research on voting in the U.S. House that has uncovered no meaningful differences in the roll call ideology of male and female representatives (Frederick 2009; Schwindt-Bayer and Corbetta 2004; Simon and Palmer 2010). The extreme polarization in the House and the rigid control the majority party has over the rules of the institution do not foster conditions where gender differences can be readily observed. As the political environment in the House is presently constituted one should not expect this phenomenon to change anytime in the near future. Nevertheless, the current state of affairs should not be interpreted as contradicting earlier studies finding gender differences in policy representation. As Frederick (2009) carefully documents in an extended time series analysis, female House members, particularly female Republicans, were distinctive in their voting behavior 
during the 1980s and 1990s. However, with an influx of more conservative women over the past few election cycles such differences have waned. While male and female representatives in the House Democratic and Republican caucuses have converged in the type of voting records they compile, there could still be differences in other types of legislative behavior. Nevertheless, on this key metric gender has almost been relegated to status of insignificant predictor.

Second, the role of gender within the parties varies substantially. Over most of the past two decades the voting records of Democrats in both the House Democrats have been strongly in harmony with another. Female House Democrats vote in a more liberal fashion than other Democrats but this tendency is largely a reaction to their more liberal constituencies. Once the overwhelming liberal composition of the districts they represent is controlled for, their voting records on the left-right continuum are virtually indistinguishable from other Democrats in Congress. As other scholars have established (Wolbrecht 2000), male Democratic politicians at the national level have largely embraced the women's rights agenda causing a convergence in the policy records within the party that transcends gender. This development does not mean there are no major differences in the way male and female Democrats behave in elected office, but they are not in evidence in this area of inquiry.

On the other side of the partisan aisle, a gender divide is still at work within the Republican Party. Republican women have long been at odds with their party on key issues that have defined the modern feminist movement. A position which has driven their voting behavior leftward, according to numerous studies that have examined the subject (Boles and Scheurer 2007; Burrell 1994; Evans 2005; Frederick 2009, 2010; Swers 1998, 2002; Tatalovich and Schier 1993). While the parties have become highly polarized around much of this agenda some female Republicans have not consistently embraced the party line on these questions. However, when it comes to Congress virtually all of these women are now serving in the U.S. Senate (Frederick 2010).

This observation marks the final contribution of this study. The institutional framework in which legislators serve is a critical variable in fully appreciating how gender influences the political landscape (Dodson 2006; Swers 2002). Although the Senate has grown more polarized in recent years (Lee 2009), it still offers more opportunities for its members to exert their individual concerns in the legislative process. For female Republicans in the Senate they can initiate and react to the legislative agenda in ways that do not conform to the prevailing Republican platform. At least over the past three congresses Republican women have been a small but moderating force within the Senate GOP Conference. Although they consistently display a 
pattern of translating descriptive representation into substantive representation, this impact is constrained by their meager numerical presence in the Senate. As long as their numbers remain so small the capacity female GOP senators to bring a unique voice in the policy process will be stymied. Besides their small numbers in Congress it is not entirely clear that as more Republican women are elected to the Senate they will be in the mold of Senators Snowe and Collins of Maine. It is entirely possible that the electoral environment in the Republican Party could drive women in the Senate as far to the right ad their colleagues in the House. At this point such an argument is speculative and can only be confirmed as more Republican women get elected to the U.S. Senate. In the meantime scholars of women in American politics should be vigilant in monitoring multiple areas of legislative activity where gender can provide insight into the behavior of members of Congress.

\section{NOTES}

${ }^{1}$ For a more detailed explanation of ideal point estimation across legislative chambers in roll call voting see: Poole (2005) and Shor et al. (2010).

${ }^{2}$ Data downloaded August 1, 2012 from http://www.voteview.com/dwnomjoint.asp.

${ }^{3} \mathrm{P}$ values generated from a series of t-tests for the difference of means between each group of Republicans.

${ }^{4}$ Ledbetter v. Goodyear Tire \& Rubber Co., 550 U.S. 618 (2007).

${ }^{5}$ House Vote No. 37, 111th Congress, First Session, January 27, 2009.

${ }^{6}$ Senate Vote No. 14, 111 th Congress, First Session, January, 22, 2009.

${ }^{7}$ It could be argued that the Lilly Ledbetter vote is capturing gender differences on an issue of specific interest to women and is not well suited to represent the systematic findings reported in this study. However, since interest group ratings that indicate support for women's issues tend to be highly correlated with the first dimensional ideological space in roll call voting (Poole and Rosenthal 2007) disentangling gender effects on these types of votes is problematic and beyond the scope of this study. Another example less directly tied to women's issues, which highlights the unique ideological positioning of female Senate Republicans, was the vote in the 111th Congress to reauthorize the Children's Health Insurance Program. On final passage of the legislation all female Senate Republicans joined all Senate Democrats in voting in favor of reauthorizing the program while all but four male Senate Republicans voted against the legislation (Senate Vote No. 31, 111th Congress, First Session, January 29, 2009).

\section{REFERENCES}

Aldrich, John H., Michael Brady, Scott de Marchi, Ian McDonald, Brendan Nyhan, David W. Rohde, and Michael Tofias. 2008. Party and Constituency in the U.S. Senate, 1933-2004. In Why Not Parties? Party Effects in the United States Senate, 
eds. Nathan Monroe, Jason M. Roberts, and David W. Rohde. Chicago: University of Chicago Press.

Ardoin, Phillip J., and James C. Garrand. 2003. Measuring Constituency Ideology in U.S. House Districts: A Top Down Simulation Approach. Journal of Politics 65:11651189.

Binder, Sarah A., and Steven Smith. 1997. Politics or Principle: Filibustering in the U.S. Senate. Washington, DC: Brookings Institution.

Boles, Janet K., and Katherine Scheurer. 2007. Beyond Women, Children and Families: Gender, Representation, and Public Funding for the Arts. Social Science Quarterly 88:39-50.

Boyd, Christina L., Lee Epstein, and Andrew D. Martin. 2010. Untangling the Causal Effects of Sex on Judging. American Journal of Political Science 54:389-411.

Brady, David, and Edward P. Schwartz. 1995. Ideology and Interests and Interests in Congressional Voting: The Politics of Voting in the U.S. Senate. Public Choice 85:25-48.

Burrell, Barbara C. 1994. A Woman's Place is in the House: Campaigns for Congress in the Feminist Era. Ann Arbor: University of Michigan Press.

Clark, Janet. 1998. Women at the National Level: An Update on Roll Call Voting Behavior. In Women in Elective Office: Past, Present, and Future, eds. Sue Thomas and Clyde Wilcox. New York: Oxford University Press.

Cox, Gary W., and Matthew D. McCubbins. 2005. Setting the Agenda: Responsible Party Government in the U.S. House of Representatives. Cambridge: Cambridge University Press.

Davidson, Roger H., Walter J. Oleszek, and Francis E. Lee. 2009. Congress and Its Members. Washington, DC: CQ Press.

Dodson, Debra L. 2006. The Impact of Women in Congress. Oxford: Oxford University Press.

Dolan, Julie. 1997. Support Form Women's Interests in the 103rd Congress: The Distinct Impact of Congressional Women. Women and Politics 18:81-94.

Erikson, Robert S., and Gerald C. Wright. 2008. Voters, Candidates and Issues in Congressional Elections. In Congress Reconsidered, 9th ed., eds. Lawrence Dodd and Bruce Oppenheimer. Washington, DC: CQ Press.

Evans, Jocelyn Jones. 2005. Women, Partisanship and the Congress. New York: Palgrave MacMillan.

Fleisher, Richard, and John R. Bond. 2004. The Shrinking Middle in the U.S. Congress. British Journal of Political Science 34:429-451.

Francovic, Kathleen. 1977. Sex and Voting in the U.S. House of Representatives: 19611975. American Politics Quarterly 5:515-530.

Frederick, Brian. 2009. Are Women Still More Liberal in a Polarized Era? The Conditional Nature of the Relationship between the Descriptive and Substantive Representation. Congress and the Presidency 36:181-202.

Frederick, Brian. 2010. Gender and Patterns of Roll Call Voting in the U.S. Senate. Congress and Presidency 37:103-124.

Frederick, Brian. 2011. Gender Turnover and Roll Call Voting in the U.S. Senate. Journal of Women Politics and Policy 32:193-210.

Fridkin, Kim L., and Gina Serignese Woodall. 2005. Different Portraits, Different Leaders? Gender Differences in U.S. Senators' Presentation of Self. In Women and Elective Office: Past, Present, and Future, eds. Sue Thomas and Clyde Wilcox. Oxford: Oxford University Press. 
Gailmard, Sean, and Jeffery A. Jenkins. 2008. Minority-Party Power in the Senate and House of Representatives. In Why Not Parties? Party Effects in the United States Senate, eds. Nathan Monroe, Jason M. Roberts, and David W. Rohde. Chicago: University of Chicago Press.

Gerrity, Jessica C., Tracy Osborn, and Jeanette Morehouse Mendez. 2007. Women and Representation: A Different View of the District? Politics \& Gender 3:179-200.

Hetherington, Marc J. 2009. Putting Polarization in Perspective. British Journal of Political Science 39:413-448.

Lee, Francis E. 2008. Dividers, Not Uniters: Presidential Leadership and Senate Partisanship, 1981-2004. Journal of Politics 70:914-928.

Lee, Francis E. 2009. Beyond Ideology: Politics, Principles, and Partisanship in the U.S. Senate. Chicago: University of Chicago Press.

Jacobson, Gary C. 2000. Party Polarization in National Politics: The Electoral Connection. In Polarized Politics: Congress and the President in a Partisan Era, eds. John R. Bond and Richard Fleischer. Washington, DC: Congressional Quarterly Press.

Jacobson, Gary C. 2009. The Politics of Congressional Elections, 7th ed. New York: Pearson Longman.

Osborn, Tracy, and Jeanette Moorhouse Menendez. 2010. Speaking as Women: Women and Floor Speeches in the Senate. Journal of Women Politics and Policy 31:1-21.

Palmer, Barbara, and Dennis Simon. 2008. Breaking the Political Glass Ceiling: Women and Congressional Elections, 2nd ed. New York: Routledge.

Pearson, Kathryn L. 2008. Party Loyalty and Discipline in the Individualistic Senate. In Why Not Parties? Party Effects in the United States Senate, eds. Nathan Monroe, Jason M. Roberts, and David W. Rohde. Chicago: University of Chicago Press.

Pearson, Kathryn L. 2009. Gendered Partisanship in the U.S. House and Senate. Paper presented at the Conference on Legislative Elections, Process and Policy: The Influence of Bicameralism, Vanderbilt University, October 22-24.

Peters, Ronald M., and Cindy Simon Rosenthal. 2010. Speaker Nancy Pelosi and the New American Politics. Oxford: Oxford University Press.

Poole, Keith T. 2005. Spatial Models of Parliamentary Voting. New York: Cambridge University Press.

Poole, Keith T., and Howard Rosenthal. 2007. Ideology and Congress. Piscataway, NJ: Transaction Publishers.

Reingold, Beth. 2008. Women as Officeholders: Linking Descriptive and Substantive Representation. In Political Women and American Democracy, eds. Christina Wolbrecht, Karen Beckwith and Lisa Baldez. Cambridge: Cambridge University Press.

Rocca, Michael S., Gabriel R. Sanchez, and Joseph Uscinski. 2008. Personal Attributes and Latino Voting Behavior in Congress. Social Science Quarterly 89:392-405.

Schickler, Eric. 2005. Institutional Development of Congress. In Institutions of American Democracy: The Legislative Branch, eds., Paul J. Quirk and Sarah A. Binder. Oxford: Oxford University Press.

Schwindt-Bayer, Leslie A., and Renato Corbetta. 2004. Gender Turnover and Roll-Call Voting in the U.S. House of Representatives. Legislative Studies Quarterly 29:215229.

Shor, Boris, Christopher Berry, and Nolan McCarthy. 2010. A Bridge to Somewhere: Mapping State and Congressional Ideology on a Cross-institutional Common Space. Legislative Studies Quarterly 35:417-448. 
Simon, Dennis M., and Barbara Palmer 2010. The Roll Call Voting Behavior of Men and Women in the U.S. House of Representatives, 1937-2008. Politics and Gender 6:225-246.

Sinclair, Barbara. 2006. Party Wars: Polarization and the Politics of National Policy Making. Norman: University of Oklahoma Press.

Sinclair, Barbara. 2007. Unorthodox Lawmaking: New Legislative Processes in the U.S. Congress, 3rd ed. Washington, DC: CQ Press.

Sinclair, Barbara. 2009. The New World of U.S. Senators. In Congress Reconsidered, 9th ed., eds. Lawrence Dodd and Bruce Oppenheimer. Washington, DC: CQ Press.

Sorok, Carolyn. 2010. Closing the Gap Legislatively: Consequences of the Lilly Ledbetter Fair Pay Act. Chicago Kent Law Review 85:1199.

Stonecash, Jeffrey M. 2006. Political Parties Matter: Realignment and the Return of Partisan Voting. Boulder, CO: Lynne Reinner Publishers.

Swers, Michele L. 1998. Are Women More Likely to Vote for Women's Issue Bills than Their Male Colleagues? Legislative Studies Quarterly 23:435-448.

Swers, Michele L. 2002. The Difference Women Make: The Policy Impact of Women in Congress. Chicago: University of Chicago Press.

Swers, Michele L. 2007. Building a Reputation on National Security: The Impact of Stereotypes Related to Gender and Military Experience. Legislative Studies Quarterly 32:559-596.

Swers, Michele L. 2008. Policy Leadership Beyond 'Women's Issues.' In Legislative Women: Getting Elected, Getting Ahead, ed. Beth Reingold. Boulder, CO: Lynne Reinner Publishers.

Tatalovich, Raymond, and David Schier. 1993. The Persistence of Ideological Cleavage in Voting on Abortion Legislation in the House of Representatives. American Politics Research 21:125-139.

Theriault, Sean M. 2008. Party Polarization in Congress. Cambridge: Cambridge University Press.

Tomz, Michael, Jason Wittenberg, and Gary King. 2003. CLARIFY: Software for Interpreting and Presenting Statistical Results. Version 2.1 Cambridge, MA: Harvard University. http://gking.harvard.edu.

Wawro, Gregory J., and Eric Schickler. 2006. Filibuster: Obstruction and Lawmaking in the U.S. Senate. Princeton, NJ: Princeton University Press.

Welch, Susan. 1985. Are Women More Liberal than Men in the U.S. Congress? Legislative Studies Quarterly 10:125-134.

Wolbrecht, Christina. 2000. The Politics of Women's Rights: Parties, Positions and Change. Princeton, NJ: Princeton University Press. 